\title{
ASSESSMENT OF WELFARE AND HEALTH OF DAIRY COWS UNDER DIFFERENT HOUSING AND MANAGEMENT SYSTEMS
}

\author{
Ahmed.S. Mostafa ${ }^{{ }^{*}}$ and Hesham. A. Mahran ${ }^{2}$ \\ ${ }^{1}$ Department of Animal Behaviour, Management and Development of Animal Wealth, Faculty of Veterinary \\ Medicine, El-Minia University, El-Minia, Egypt. \\ ${ }^{2}$ Department of Hygiene, Management and Zoonoses, Faculty of Veterinary Medicine, Beni-suef Univesity, \\ Egypt. \\ *Corresponding author: Ahmed.S. Mostafa; E-mail : drasmostafa69@gmail.com
}

\begin{abstract}
This study was conducted in six dairy farms in Beni-Suef Governorate representing the most prevalent systems of housing and management in Egypt to assess the welfare and health of dairy cows kept in these systems. These systems including 1) tie stall barn with daily access to an outside shaded area associated with hand milking twice daily; 2) loose housing in partially sheltered yards on earthy floor represented by 4 farms with different management practices include feeding and milking, and 3) free stall barn with daily access to partially sheltered yards during the day time associated with three times daily milking in a parlour system. Each farm was visited three times over a period of one year. All cows were observed for lying and standing up behaviour and examined for lameness, mastitis, skin alterations at the knee and hock joints and rest of the body, teat injuries, cleanliness of the hind legs and udder, and body condition score. Results revealed that no restriction for lying and standing up behaviour was observed in all systems indicating that cow comfort was maintained. The prevalence of lameness was higher in loose housing system on earthy floor $(0.9,15.4$ and $8.7 \%)$. The prevalence of skin alterations at the knee joint was higher in cows kept in tie and free stall barns (4.7 and $7.5 \%$ respectively) and at hock joints $(11.9 \%)$ in tie stall barn on concrete floor. Tie stall system had a higher prevalence of teat injuries $(14.3 \%)$ than other systems. High degree of dirtiness of hind legs $(90.5,89$ and $99.2 \%)$ and udder $(91.4,91.6$ and $100 \%)$ was found in loose housing system associated with increased dampness of the floor and lack of daily cow cleaning regimen.
\end{abstract}

Keywords: Behaviour, Cattle, Housing, Lameness, Management, Welfare.

\section{Original Article:}

DOI:https://dx.doi.org/10.21608/javs.2016.62122

Received : 10 August. 2016

Accepted: 27 September, 2016

Published: 14 October, 2016

This is an open access article under the term of the Creative Commons Attribution 4.0 (CC-BY) International License. To view a copy of this license, visit:http://creativecommons.org/licenses/by/4.0/

J. Appl. Vet. Sci., 1(1):56-68.

\section{INTRODUCTION}

The concept of animal welfare is not established in Egypt till now which may be related to level of education, culture, economic status of the country and priorities of cattle breeders and the society. Throughout the world, dairy cattle are managed under a wide variety of different housing and management systems in a range of different climates. These include stanchion and tie stall barns, cubicle or free stall barns (which have now become commonplace in many countries), bedded pack (straw yard or compost) barns in areas with plentiful supplies of organic bedding material, dirt lots (dry lots) in warm dry climates, and grazing herds where cattle are either housed throughout the winter in confinement or graze all the year round depending on the climatic conditions. Dairy cows can adapt and remain productive under these different systems (Nigel and Kenneth, 2009).
In Egypt, most of dairy cows are kept either in tie stall barns or in yards under different management systems. Although there is no animal welfare legislation adopted in our country, it was found that most dairy farmers and dairy cattle keepers are satisfying cattle needs in terms of housing design, nutrition and handling in order to maintain high production and maximum profit. The major welfare problems for housed dairy cows are lameness, mastitis and difficulty in finding feeding and lying places (Fraser and Broom, 1990; Fayed, 1997). Most of these problems are associated with the design of the housing system but some are a consequence of poor stockmanship.

Farms with the same housing type might vary substantially with respect to characteristics of the stables and stalls, feeding and milking routines, skills 
of the farmer, breed of cows and other factors with a potentially large impact on health and welfare (Regula et al., 2004). Although it is widely accepted that welfare can be assessed by a combination of different measures of behaviour, skin lesions, and clinical disease (Fraser and Broom, 1990; Fregonesi and Leaver, 2001; Scott et al., 2001), there is no gold standard for the assessment of welfare. The aim of this study was to assess welfare and health of dairy cows under different housing and management systems by using behavioural and clinical measures.

\section{MATERIALS AND METHODS}

\section{Farms}

This study was carried out on six farms with different systems of housing and management in BeniSuef Governorate over a period of one year. The first farm (I) was located in the faculty of Veterinary Medicine, Beni-Suef University comprising a total number of 14 Holstein cows which were housed in a tie stall barn on a concrete floor (stall dimensions were $120 \times 200 \mathrm{~cm}$ ) without addition of bedding material. Cows were hand milked twice daily and their udders and bellies were washed before each milking. Throughout the year cows were turned out into shaded areas on earthy floor outside the barn after the morning milking and returned before the evening milking. During this period the barn was cleaned from dung by scraping and flushing with water. The second farm (II) was located in Naser city with a herd size of 70 Holstein-Friesian cows housed in partially sheltered and fenced yards on earthy floor with a stocking density of one cow $/ 10 \mathrm{~m}^{2}$. Cows were milked twice daily using portable milking machine.

The third farm (III) was located in Naser city with a herd size of 115 Holstein-Friesian cows housed in partially sheltered and fenced yards on earthy floor with a stocking density of one cow $/ 8-10 \mathrm{~m}^{2}$. Cows were milked three times daily using portable milking machine. Before milking, the udder of each cow was washed with tap water. The fourth farm (IV) was located in Beni-Suef city with a herd size of 80 Friesian cows housed in a partially sheltered yard on earthy floor with a stocking density of one cow $/ 8 \mathrm{~m}^{2}$. Cows were milked twice daily by using portable milking machine without any udder washing or preparation. After the morning milking cows were turned into cultivated lands for grazing and returned before the second milking.

The fifth farm (V) was located in Ihnasia city with a herd size of 400 Holstein cows kept free in partially sheltered yards on earthy floor with a stocking density of one cow/15-20 $\mathrm{m}^{2}$. Cows were milked three times daily in a herring bone milking parlour. The udder and teats of each cow was washed with water and then disinfected with diluted iodine solution and dried with disposable towels. The sixth farm (VI) was located in Elwasta city with a herd size of 160 Holstein cows housed in a free stall barn on a concrete floor with daily access to partially sheltered yards on earthy floor with a stocking density of one cow/12 $\mathrm{m}^{2}$ during the day time. Cows were milked three times daily in a herring bone milking parlour. Udders of cows were washed thoroughly before each milking.

\section{Welfare and health indicators}

Each farm was visited three times by the authors throughout the study period to assess the welfare and health status of cows in the examined farms and to stand on any changes that occur in both housing and management systems. Each visit was lasted for 8-10 hours during which all cows can be examined thoroughly.The health and welfare status of cows was assessed by using a combination of assessment methods including behavioural observations, evaluation of skin alterations indicative of poor 'cow comfort', clinical examination and health records.

\section{Behavioural observations \\ Quality of lying behaviour}

The quality of lying behaviour was scored on a scale from 'not restricted or altered' to 'severely restricted or altered' according to the method described by Faull $\boldsymbol{e t}$ al., (1996). No restriction of lying behaviour was defined as the cow being able to completely stretch its legs and neck in its lying position. A slight restriction was recorded if either legs or neck could not be stretched, and severe restriction if the cow was either partly lying outside the lying area, or could not stretch either legs or neck, or (in tie stalls) was unable to lie down due to a neighboring cow resting partly at its place.

\section{Quality of standing-up behaviour}

The quality of standing-up behaviour was scored on a scale like that mentioned in lying behaviour. No restriction was recorded when cows can stand without any restriction. A slight restriction was recorded if the cow rested on its knee joints for more than 10 seconds. Cows needing more than one attempt for rising or standing up atypically (starting with the front legs rather than the hind legs) were scored as severely restricted.

\section{Assessment of lameness}

An assessment of lameness was performed according to the method described by Manson and Leaver (1988). In tie stalls, cows were observed when they turned out into the shaded area outside the barn in the morning after milking. In loose-housing systems, all cows were observed during movement to the 
collecting area or parlour through the race, and the suspected cows were further thoroughly examined. Each cow was observed while walking, and a score from 1 (regular gait) to 5 (severe lameness) was assigned.

\section{Skin alterations}

Skin alterations were evaluated by a method that had been established by Krebs et al., (2001). The skin around the hock joints was examined visually, and scored as 0 (no alteration), 1 (hairless patch, but skin unaltered), 2 (reddening and/or swelling of skin), or 3 (open wound or abscess). If the scores from the two hock joints differed, the higher score was recorded. At the knee joints, presence of thickened skin or a palpable artificial bursa under the skin was noted as 'callosity'. At the skin of the rest of the body, the number and severity of injuries were recorded. All teats were examined visually and manually for injuries or scars.

\section{Cleanliness}

Cleanliness was evaluated at the hind legs and the udder by the method described by Faye and Barnouin (1985). The udder was evaluated as 'clean' when less than $10 \%$ of the area of the udder skin was covered with dirt. Dirt on between $10 \%$ and $50 \%$ of the skin area was scored as 'dirty'; more than $50 \%$ of the skin area covered with dirt was scored as "very dirty'. The cleanliness of the skin area of each hind leg was scored with the same system. The score of the dirtier hind leg was used in the analyses.

\section{Body condition score}

Body condition score is indicative for health and welfare of cows. A body-condition score (BCS) on a scale from 1 to 5 was assigned to each cow according to the method described by Edmonson $\boldsymbol{e t}$ al,. (1989). Cows were classified as ideal (above 2.5 and below 4), under-conditioned (below 2.5) or overconditioned (above 4).

\section{Statistical analysis}

The obtained results were analyzed by one way ANOVA using SPSS for Windows (Release 20.0 standard version, IBM Corporation, Chicago, Illinois). The differences were considered statistically significant when $\mathrm{P}<0.05$. The mean percentage and prevalence was calculated from the data obtained during the three visits of each farm (Espejo et al., 2006).

\section{RESULTS}

Table1. Effect of housing and management on quality of lying behavior

\begin{tabular}{|c|c|c|c|c|c|c|c|c|}
\hline \multirow{2}{*}{ Farms } & \multirow{2}{*}{ Lying behaviour } & \multicolumn{6}{|c|}{ Quality of lying behaviour } \\
\cline { 3 - 9 } & $\mathrm{n}$ & $\%$ & $\mathrm{n}$ & $\%$ & $\mathrm{~N}$ & $\%$ & $\mathrm{n}$ & $\%$ \\
\hline & 20 & $\begin{array}{c}47.6^{\mathrm{a}} \\
\pm 0.63\end{array}$ & 42 & $100 \pm 0.00$ & 0 & $0 \pm 0.00$ & 0 & $0 \pm 0.00$ \\
\hline I & 20 altericted or & \multicolumn{2}{|c|}{ Slight restricted } & \multicolumn{2}{c|}{$\begin{array}{c}\text { Severely } \\
\text { restricted }\end{array}$} \\
\hline II & 11 & $5.3^{\mathrm{b}} \pm 0.31$ & 210 & $100 \pm 0.00$ & 0 & $0 \pm 0.00$ & 0 & $0 \pm 0.00$ \\
\hline III & 27 & $7.8^{\mathrm{b}} \pm 0.40$ & 345 & $100 \pm 0.00$ & 0 & $0 \pm 0.00$ & 0 & $0 \pm 0.00$ \\
\hline IV & 15 & $\begin{array}{c}6.3^{\mathrm{b}} \\
\pm 0.40\end{array}$ & 240 & $100 \pm 0.00$ & 0 & $0 \pm 0.00$ & 0 & $0 \pm 0.00$ \\
\hline V & 62 & $5.2^{\mathrm{b}} \pm 0.07$ & 1200 & $100 \pm 0.00$ & 0 & $0 \pm 0.00$ & 0 & $0 \pm 0.00$ \\
\hline VI & 40 & $8.3^{\mathrm{b}} \pm 0.23$ & 480 & $100 \pm 0.00$ & 0 & $0 \pm 0.00$ & 0 & $0 \pm 0.00$ \\
\hline
\end{tabular}

Results are expressed as means \pm SE calculated from data obtained during the three visits ${ }_{\mathrm{a}, \mathrm{b}}$ superscripts within columns indicate significant difference at $p<0.01$ 
Table 2. Effect of housing and management on quality of standing behaviour

\begin{tabular}{|c|c|c|c|c|c|c|c|c|}
\hline \multirow{2}{*}{ Farms } & \multicolumn{2}{|c|}{ Standing behaviour } & \multicolumn{2}{|c|}{ Not restricted or altered } & \multicolumn{2}{|c|}{ Slight restricted } & \multicolumn{2}{|c|}{ Severely restricted } \\
\cline { 2 - 8 } & $\mathrm{n}$ & $\%$ & $\mathrm{n}$ & $\%$ & $\mathrm{n}$ & $\%$ & $\mathrm{n}$ & $\%$ \\
\hline I & 22 & $52.4^{\mathrm{b}} \pm 0.63$ & 42 & $100 \pm 0.00$ & 0 & $0 \pm 0.00$ & 0 & $0 \pm 0.00$ \\
\hline II & 199 & $94.7^{\mathrm{a}} \pm 0.31$ & 210 & $100 \pm 0.00$ & 0 & $0 \pm 0.00$ & 0 & $0 \pm 0.00$ \\
\hline III & 318 & $92.2^{\mathrm{a}} \pm 0.40$ & 345 & $100 \pm 0.00$ & 0 & $0 \pm 0.00$ & 0 & $0 \pm 0.00$ \\
\hline IV & 225 & $93.7^{\mathrm{a}} \pm 0.40$ & 240 & $100 \pm 0.00$ & 0 & $0 \pm 0.00$ & 0 & $0 \pm 0.00$ \\
\hline V & 1138 & $94.8^{\mathrm{a}} \pm 0.07$ & 1200 & $100 \pm 0.00$ & 0 & $0 \pm 0.00$ & 0 & $0 \pm 0.00$ \\
\hline VI & 440 & $91.7^{\mathrm{a}} \pm 0.23$ & 480 & $100 \pm 0.00$ & 0 & $0 \pm 0.00$ & 0 & $0 \pm 0.00$ \\
\hline
\end{tabular}

Results are expressed as means \pm SE calculated from data obtained during the three visits ${ }^{\mathrm{a}, \mathrm{b}}$ superscripts within columns indicate significant difference at $p<0.01$

Table 3. Effect of housing and management on prevalence of lameness

\begin{tabular}{|c|c|c|c|c|c|c|c|c|c|c|}
\hline \multirow{2}{*}{ Farms } & \multicolumn{2}{|c|}{ Score 1 } & \multicolumn{2}{|c|}{ Score 2 } & \multicolumn{2}{|c|}{ Score 3 } & \multicolumn{2}{|c|}{ Score 4 } & \multicolumn{2}{c|}{ Score 5 } \\
\cline { 2 - 10 } & $\mathrm{n}$ & $\%$ & $\mathrm{n}$ & $\%$ & $\mathrm{n}$ & $\%$ & $\mathrm{n}$ & $\%$ & $\mathrm{n}$ & $\%$ \\
\hline I & 33 & $78.5^{\mathrm{d}} \pm 1.10$ & 9 & $21.5^{\mathrm{a}} \pm 1.10$ & 0 & $0.0^{\mathrm{c}} \pm 0.0$ & 0 & $0.0^{\mathrm{b}} \pm 0.0$ & 0 & $0.0^{\mathrm{c}} \pm 0.0$ \\
\hline II & 197 & $93.8^{\mathrm{ab}} \pm 0.20$ & 0 & $0.0^{\mathrm{b}} \pm 0.0$ & 13 & $6.2^{\mathrm{a}} \pm 0.20$ & 0 & $0.0^{\mathrm{b}} \pm 0.0$ & 0 & $0.0^{\mathrm{c}} \pm 0.0$ \\
\hline III & 329 & $95.3^{\mathrm{a}} \pm 0.07$ & 9 & $2.6^{\mathrm{b}} \pm 0.04$ & 4 & $1.2^{\mathrm{c}} \pm 0.02$ & 0 & $0.0^{\mathrm{b}} \pm 0.0$ & 3 & $0.9^{\mathrm{c}} \pm 0.31$ \\
\hline IV & 203 & $84.6^{\mathrm{cd}} \pm 0.20$ & 0 & $0.0^{\mathrm{b}} \pm 0.0$ & 0 & $0.0^{\mathrm{c}} \pm 0.0$ & 0 & $0.0^{\mathrm{b}} \pm 0.0$ & 37 & $15.4^{\mathrm{a}} \pm 0.20$ \\
\hline V & 1050 & $87.5^{\mathrm{bc}} \pm 0.07$ & 10 & $0.8^{\mathrm{b}} \pm 0.01$ & 21 & $1.8 \mathrm{~b}^{\mathrm{c}} \pm 0.01$ & 14 & $1.2^{\mathrm{a}} \pm 0.01$ & 105 & $8.7^{\mathrm{b}} \pm 0.11$ \\
\hline VI & 436 & $90.8^{\mathrm{abc}} \pm 0.14$ & 20 & $4.2^{\mathrm{b}} \pm 0.03$ & 24 & $5.0^{\mathrm{ab}} \pm 0.17$ & 0 & $0.0^{\mathrm{b}} \pm 0.0$ & 0 & $0.0^{\mathrm{c}} \pm 0.0$ \\
\hline
\end{tabular}

Results are expressed as means \pm SE calculated from data obtained during the three visits ${ }_{\mathrm{a}, \mathrm{b}, \mathrm{c}, \mathrm{d}}$ superscripts within columns indicate significant difference at $p<0.01$

Table 4. Effect of housing and management on prevalence of clinical mastitis

\begin{tabular}{|c|c|c|}
\hline \multirow{2}{*}{ Farms } & \multicolumn{2}{|c|}{ Prevalence of clinical mastitis } \\
\cline { 2 - 3 } & $\mathrm{n}$ & $\%$ \\
\hline I & 4 & $9.52^{\mathrm{bc}} \pm 0.63$ \\
\hline II & 19 & $9.04^{\mathrm{cd}} \pm 0.14$ \\
\hline III & 45 & $13.04^{\mathrm{b}} \pm 0.09$ \\
\hline IV & 50 & $20.83^{\mathrm{a}} \pm 0.12$ \\
\hline V & 102 & $8.5^{\mathrm{cd}} \pm 0.02$ \\
\hline VI & 25 & $5.2^{\mathrm{d}} \pm 0.04$ \\
\hline
\end{tabular}

Results are expressed as means $\pm \mathrm{SE}$ calculated from data obtained during the three visits $\mathrm{a}, \mathrm{b}, \mathrm{c}, \mathrm{d}$ superscripts within columns indicate significant difference at $p<0.01$ 
Ahmed.S. Mostafa and Hesham. A. Mahran

Table 5. Effect of housing and management on prevalence of skin alterations

\begin{tabular}{|c|c|c|c|c|c|c|c|c|c|c|c|c|}
\hline \multirow{3}{*}{ Farms } & \multicolumn{8}{|c|}{ Around hock joint } & \multirow{2}{*}{\multicolumn{2}{|c|}{$\begin{array}{c}\text { Around } \\
\text { knee joint }\end{array}$}} & \multirow{2}{*}{\multicolumn{2}{|c|}{$\begin{array}{l}\text { Rest of the } \\
\text { body }\end{array}$}} \\
\hline & \multicolumn{2}{|c|}{ Score $(0)$} & \multicolumn{2}{|c|}{ Score (1) } & \multicolumn{2}{|c|}{ Score (2) } & \multicolumn{2}{|c|}{ Score (3) } & & & & \\
\hline & $\mathrm{n}$ & $\%$ & $\mathrm{n}$ & $\%$ & $\mathrm{n}$ & $\%$ & $\mathrm{n}$ & $\%$ & $\mathrm{n}$ & $\%$ & $\mathrm{n}$ & $\%$ \\
\hline I & 32 & $\begin{array}{c}76.2^{\mathrm{b}} \\
\pm \\
0.64 \\
\end{array}$ & 5 & $\begin{array}{c}11.9^{\mathrm{a}} \\
\pm \\
1.27 \\
\end{array}$ & 5 & $\begin{array}{c}11.9^{\mathrm{a}} \\
\pm \\
0.63 \\
\end{array}$ & 0 & $\begin{array}{c}0.0 \\
\pm \\
0.0 \\
\end{array}$ & 2 & $\begin{array}{c}4.7^{\mathrm{a}} \\
\pm \\
0.63 \\
\end{array}$ & 0 & $\begin{array}{c}0.0 \\
\pm \\
0.0 \\
\end{array}$ \\
\hline II & $\begin{array}{c}20 \\
4\end{array}$ & $\begin{array}{c}97.1^{\mathrm{a}} \\
\pm \\
0.10\end{array}$ & 6 & $\begin{array}{c}2.9^{\mathrm{b}} \\
\pm \\
0.10\end{array}$ & 0 & $\begin{array}{c}0.0^{\mathrm{b}} \\
\pm \\
0.0\end{array}$ & 0 & $\begin{array}{c}0.0 \\
\pm \\
0.0\end{array}$ & 4 & $\begin{array}{c}1.9^{\mathrm{b}} \\
\pm \\
0.09\end{array}$ & 0 & $\begin{array}{c}0.0 \\
\pm \\
0.0\end{array}$ \\
\hline III & $\begin{array}{c}34 \\
2\end{array}$ & $\begin{array}{c}99.1^{\mathrm{a}} \\
\pm \\
0.04\end{array}$ & 3 & $\begin{array}{c}0.9^{\mathrm{b}} \\
\pm \\
0.04\end{array}$ & 0 & $\begin{array}{c}0.0^{\mathrm{b}} \\
\pm \\
0.0\end{array}$ & 0 & $\begin{array}{c}0.0 \\
\pm \\
0.0 \\
\end{array}$ & 5 & $\begin{array}{c}1.4^{\mathrm{b}} \\
\pm \\
0.06\end{array}$ & 0 & $\begin{array}{c}0.0 \\
\pm \\
0.0\end{array}$ \\
\hline IV & $\begin{array}{c}23 \\
7\end{array}$ & $\begin{array}{c}98.8^{\mathrm{a}} \\
\pm \\
0.08\end{array}$ & 3 & $\begin{array}{c}1.2^{\mathrm{b}} \\
\pm \\
0.08\end{array}$ & 0 & $\begin{array}{c}0.0^{\mathrm{b}} \\
\pm \\
0.0\end{array}$ & 0 & $\begin{array}{c}0.0 \\
\pm \\
0.0\end{array}$ & 4 & $\begin{array}{c}1.6^{\mathrm{b}} \\
\pm \\
0.07\end{array}$ & 0 & $\begin{array}{c}0.0 \\
\pm \\
0.0\end{array}$ \\
\hline V & $\begin{array}{l}11 \\
91\end{array}$ & $\begin{array}{c}99.3^{\mathrm{a}} \\
\pm \\
0.01\end{array}$ & 9 & $\begin{array}{c}0.7^{\mathrm{b}} \\
\pm \\
0.01\end{array}$ & 0 & $\begin{array}{c}0.0^{\mathrm{b}} \\
\pm \\
0.0\end{array}$ & 0 & $\begin{array}{c}0.0 \\
\pm \\
0.0\end{array}$ & 18 & $\begin{array}{c}1.5^{\mathrm{b}} \\
\pm \\
0.01\end{array}$ & 0 & $\begin{array}{c}0.0 \\
\pm \\
0.0\end{array}$ \\
\hline VI & $\begin{array}{c}47 \\
7\end{array}$ & $\begin{array}{c}99.4^{\mathrm{a}} \\
\pm \\
0.02\end{array}$ & 3 & $\begin{array}{c}0.6^{\mathrm{b}} \\
\pm \\
0.02\end{array}$ & 0 & $\begin{array}{c}0.0^{\mathrm{b}} \\
\pm \\
0.0\end{array}$ & 0 & $\begin{array}{c}0.0 \\
\pm \\
0.0\end{array}$ & 36 & $\begin{array}{c}7.5^{\mathrm{a}} \\
\pm \\
0.02\end{array}$ & 0 & $\begin{array}{c}0.0 \\
\pm \\
0.0\end{array}$ \\
\hline
\end{tabular}

Results are expressed as means \pm SE calculated from data obtained during the three visits ${ }^{\mathrm{a}, \mathrm{b}}$ superscripts within columns indicate significant difference at $p<0.01$

Table 6. Effect of housing and management on prevalence of teat injuries

\begin{tabular}{|c|c|c|c|c|c|c|c|c|c|c|}
\hline \multirow{3}{*}{ Farms } & \multirow{2}{*}{\multicolumn{2}{|c|}{$\begin{array}{l}\text { Prevalence of } \\
\text { teat injuries }\end{array}$}} & \multicolumn{8}{|c|}{ Severity of Teat Injuries } \\
\hline & & & \multicolumn{2}{|c|}{ One teat } & \multicolumn{2}{|c|}{ Two teats } & \multicolumn{2}{|c|}{ Three teats } & \multicolumn{2}{|c|}{ Four teats } \\
\hline & $\mathrm{n}$ & $\%$ & $\mathrm{n}$ & $\%$ & $\mathrm{n}$ & $\%$ & $\mathrm{n}$ & $\%$ & $\mathrm{n}$ & $\%$ \\
\hline $\mathrm{I}$ & 6 & $14.3^{\mathrm{a}} \pm 1.3$ & 6 & $\begin{array}{l}100.0^{\mathrm{a}} \\
\pm 0.00\end{array}$ & 0 & $0.0^{\mathrm{b}} \pm 0.0$ & 0 & $\begin{array}{c}0.0 \\
\pm 0.0\end{array}$ & 0 & $\begin{array}{c}0.0 \\
\pm 0.0\end{array}$ \\
\hline II & 2 & $0.9^{\mathrm{b}} \pm 0.05$ & 2 & $\begin{array}{l}100.0^{\mathrm{a}} \\
\pm 0.00\end{array}$ & 0 & $0.0^{\mathrm{b}} \pm 0.0$ & 0 & $\begin{array}{c}0.0 \\
\pm 0.0\end{array}$ & 0 & $\begin{array}{c}0.0 \\
\pm 0.0\end{array}$ \\
\hline III & 3 & $0.8^{\mathrm{b}} \pm 0.04$ & 3 & $\begin{array}{l}100.0^{\mathrm{a}} \\
\pm 0.00\end{array}$ & 0 & $0.0^{\mathrm{b}} \pm 0.0$ & 0 & $\begin{array}{c}0.0 \\
\pm 0.0\end{array}$ & 0 & $\begin{array}{c}0.0 \\
\pm 0.0\end{array}$ \\
\hline IV & 9 & $3.8^{\mathrm{b}} \pm 0.08$ & 9 & $\begin{array}{l}100.0^{\mathrm{a}} \\
\pm 0.00\end{array}$ & 0 & $0.0^{\mathrm{b}} \pm 0.0$ & 0 & $\begin{array}{c}0.0 \\
\pm 0.0\end{array}$ & 0 & $\begin{array}{c}0.0 \\
\pm 0.0\end{array}$ \\
\hline $\mathrm{V}$ & $\begin{array}{l}1 \\
5\end{array}$ & $1.3^{\mathrm{b}} \pm 0.02$ & $\begin{array}{l}1 \\
5\end{array}$ & $\begin{array}{l}100.0^{\mathrm{a}} \\
\pm 0.00\end{array}$ & 0 & $0.0^{\mathrm{b}} \pm 0.0$ & 0 & $\begin{array}{c}0.0 \\
\pm 0.0\end{array}$ & 0 & $\begin{array}{c}0.0 \\
\pm 0.0\end{array}$ \\
\hline VI & $\begin{array}{l}2 \\
6\end{array}$ & $5.4^{\mathrm{b}} \pm 0.08$ & 0 & $0.0^{\mathrm{b}} \pm 0.0$ & $\begin{array}{l}2 \\
6\end{array}$ & $\begin{array}{c}100.0^{\mathrm{a}} \\
\pm 0.0\end{array}$ & 0 & $\begin{array}{c}0.0 \\
\pm 0.0\end{array}$ & 0 & $\begin{array}{c}0.0 \\
\pm 0.0\end{array}$ \\
\hline
\end{tabular}

Results are expressed as means \pm SE calculated from data obtained during the three visits ${ }^{\mathrm{a}, \mathrm{b}}$ superscripts within columns indicate significant difference at $p<0.01$ 
Table 7. Effect of housing and management on cleanliness of hind legs of cows

\begin{tabular}{|c|c|c|c|c|c|c|}
\hline \multirow{2}{*}{ Farms } & \multicolumn{2}{|c|}{ Clean } & \multicolumn{2}{c|}{ Dirty } & \multicolumn{2}{c|}{ Very Dirty } \\
\cline { 2 - 7 } & $\mathrm{n}$ & $\%$ & $\mathrm{n}$ & $\%$ & $\mathrm{n}$ & $\%$ \\
\hline I & 21 & $50.0^{\mathrm{b}} \pm 2.19$ & 16 & $38.1^{\mathrm{a}} \pm 2.29$ & 5 & $11.9^{\mathrm{c}} \pm 0.63$ \\
\hline II & 6 & $2.9^{\mathrm{c}} \pm 0.10$ & 14 & $6.6^{\mathrm{c}} \pm 0.14$ & 190 & $90.5^{\mathrm{b}} \pm 0.11$ \\
\hline III & 21 & $6.1^{\mathrm{c}} \pm 0.04$ & 17 & $4.9^{\mathrm{c}} \pm 0.06$ & 307 & $89.0^{\mathrm{b}} \pm 0.07$ \\
\hline IV & 0 & $0.0^{\mathrm{c}} \pm 0.0$ & 2 & $0.8^{\mathrm{c}} \pm 0.09$ & 238 & $99.2^{\mathrm{a}} \pm 0.09$ \\
\hline V & 850 & $70.9^{\mathrm{a}} \pm 0.07$ & 240 & $20.0^{\mathrm{b}} \pm 0.03$ & 110 & $9.1^{\mathrm{cd}} \pm 0.04$ \\
\hline VI & 360 & $75.0^{\mathrm{a}} \pm 0.28$ & 92 & $19.2^{\mathrm{b}} \pm 0.28$ & 28 & $5.8^{\mathrm{d}} \pm 0.03$ \\
\hline
\end{tabular}

Results are expressed as means \pm SE calculated from data obtained during the three visits ${ }^{\mathrm{a}, \mathrm{b}}$ superscripts within columns indicate significant difference at $p<0.01$

Table 8. Effect of housing and management on cleanliness of udder of cows

\begin{tabular}{|c|c|c|c|c|c|c|}
\hline \multirow{2}{*}{ Farms } & \multicolumn{2}{|c|}{ Clean } & \multicolumn{2}{|c|}{ Dirty } & \multicolumn{2}{c|}{ Very Dirty } \\
\cline { 2 - 7 } & $\mathrm{n}$ & $\%$ & $\mathrm{n}$ & $\%$ & $\mathrm{n}$ & $\%$ \\
\hline I & 39 & $92.9^{\mathrm{a}} \pm 1.10$ & 3 & $7.1^{\mathrm{b}} \pm 1.10$ & 0 & $0.0^{\mathrm{e}} \pm 0.0$ \\
\hline II & 6 & $2.9^{\mathrm{c}} \pm 0.10$ & 12 & $5.7^{\mathrm{bc}} \pm 0.09$ & 192 & $91.4^{\mathrm{b}} \pm 0.09$ \\
\hline III & 12 & $3.5^{\mathrm{c}} \pm 0.04$ & 17 & $4.9^{\mathrm{bc}} \pm 0.07$ & 316 & $91.6^{\mathrm{b}} \pm 0.11$ \\
\hline IV & 0 & $0.0^{\mathrm{c}} \pm 0.0$ & 0 & $0.0^{\mathrm{c}} \pm 0.0$ & 240 & $100.0^{\mathrm{a}} \pm 0.00$ \\
\hline V & 15 & $1.3^{\mathrm{c}} \pm 0.01$ & 120 & $10.0^{\mathrm{b}} \pm 0.07$ & 1065 & $88.7^{\mathrm{c}} \pm 0.05$ \\
\hline VI & 90 & $18.7^{\mathrm{b}} \pm 0.11$ & 144 & $30.0^{\mathrm{a}} \pm 0.15$ & 246 & $51.3^{\mathrm{d}} \pm 0.05$ \\
\hline
\end{tabular}

Results are expressed as means \pm SE calculated from data obtained during the three visits

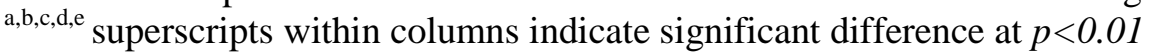

Table 9. Effect of housing and management on body condition score of cows

\begin{tabular}{|c|c|c|c|c|c|c|}
\hline \multirow{2}{*}{ Farms } & \multicolumn{2}{|c|}{ Ideal } & \multicolumn{2}{c|}{ Under condition } & \multicolumn{2}{c|}{ Over condition } \\
\cline { 2 - 7 } & $\mathrm{n}$ & $\%$ & $\mathrm{n}$ & $\%$ & $\mathrm{n}$ & $\%$ \\
\hline I & 25 & $59.5^{\mathrm{d}} \pm 0.64$ & 9 & $21.4^{\mathrm{a}} \pm 1.10$ & 8 & $19.1^{\mathrm{a}} \pm 0.63$ \\
\hline II & 194 & $92.4^{\mathrm{b}} \pm 0.05$ & 11 & $5.2^{\mathrm{b}} \pm 0.05$ & 5 & $2.4^{\mathrm{b}} \pm 0.02$ \\
\hline III & 330 & $95.7^{\mathrm{ab}} \pm 0.04$ & 6 & $1.7^{\mathrm{b}} \pm 0.04$ & 9 & $2.6^{\mathrm{b}} \pm 0.03$ \\
\hline IV & 228 & $95.0^{\mathrm{ab}} \pm 0.08$ & 6 & $2.5^{\mathrm{b}} \pm 0.08$ & 6 & $2.5^{\mathrm{b}} \pm 0.05$ \\
\hline V & 1169 & $97.4^{\mathrm{a}} \pm 0.01$ & 12 & $1.0^{\mathrm{b}} \pm 0.01$ & 19 & $1.6^{\mathrm{b}} \pm 0.02$ \\
\hline VI & 380 & $79.2^{\mathrm{c}} \pm 0.14$ & 90 & $18.7^{\mathrm{a}} \pm 0.14$ & 10 & $2.1^{\mathrm{b}} \pm 0.04$ \\
\hline
\end{tabular}

Results are expressed as means \pm SE calculated from data obtained during the three visits ${ }^{a, b, c}$ superscripts within columns indicate significant difference at $p<0.01$

\section{DISCUSSION}

The results in Tables $(1 \& 2)$ revealed that there was a significant $(\mathrm{p}<0.01)$ high percent of cows $(47.6 \%)$ were lying in tie stall system (farm I) during the visits when compared to cows in other examined farms where a high percent of cows were standing.In all examined farms, it was observed that the quality of both lying and standing behaviours was maintained and was not affected by the design of housing. In other terms, there was no restriction for the normal sequences of lying and/or standing behaviours. 
The total time spent lying per day and synchrony of lying are important indicators of cow comfort (Miller and Wood-Gush, 1991). The results in Tables $(1 \& 2)$ agree with previous observations mentioned that reduced lying behviour may be associated with high stress (Fisher et al., 2002), changes in the frequency of eating, grooming and idling behaviours (Munksgaard and Simonsen 1996), mismanaged housing facilities resulting in longer standing durations (Greenough and Vermunt, 1991; Singh et al., 1993 ; Bickert and Cermak, 1997 and Fayed, 1997). It has been found that long waiting time for access to milking can affect the time available for cows for eating and lying behaviours (Ketelaar de Lauwere et al., 1996 and Gomez and Cook, 2010).

Tie stalls offer the cow a guaranteed place to lie down and ready access to feeding space with minimal competition. However, tie-stall housing limits how much the animal can move. If cows are also milked in the stall they may be tethered for months on end. In addition, there is a lack of opportunity for close physical contact between animals, combined with an inability to escape completely from aggressive neighbours. When tied in the stall, the animal cannot turn around and may not be able to groom all parts of its body. Tie stall lying times will be influenced by the degree of restriction to the rising and lying motion and by surface area. Several studies have found that, compared to behavior in loose housing, cows restricted in tie stalls were more reluctant to change position from lying to standing, with an increased frequency of interruption of the lying down movement, extending the duration of the whole process (Krohn and Munksgaard, 1993 and Haley et al., 2000).

Loose housing with a bedded area overcomes the problem of mobility and allows physical contact between animals, but the animals are still housed in a restricted space and may not be able to escape completely from an aggressive dominant cow. Individual feeding is rarely possible so animals may need to compete for limited feed space, and they are required to eat a diet tailored to the average cow rather than to the individual. The free-stall system provides a means for the animals to escape from aggression but there may only be a limited number of places to lie down creating another source of competition. In free stall barn the time spent per cow in lying may be affected by some management factors such as parity, stage of lactation and stocking rate in addition to stall design.

Cows in farm (I) are less subjected to stress than cows in the other examined farms due to low milk production, small herd size and consequently short waiting time for access to milking in addition to lack of social aggression and competition for feeding and lying spaces as each cow was fed individually and had its own stall. Thus cows will become reassured and contented which will be reflected on the total time spent lying per day and lying synchrony. Moreover, mismanaged housing facilities represented in the lack of bedding and accumulation of mud and dung for long periods may make the place uncomfortable for lying especially in winter months.

\section{Prevalence of lameness}

Table (3) presents the descriptive statistics of the recorded prevalence of lameness in the different examined farms representing different housing and management systems. According to lameness score used to assess lameness in this study, it was clear that most cows were lying under the category of normal locomotion or gait (score1). However, the prevalence of normal gait was low $(\mathrm{p}<0.01)$ in farms I, IV and V as compared to farms II, III and VI. Prevalence of severe lameness was higher $(\mathrm{p}<0.01)$ in farms IV $(15.4 \%)$ and $\mathrm{V}(8.7 \%)$ than other examined farms.

The results concerning the prevalence of lameness (Table3) disagree with prior results (Bergsten and Herlin, 1996; Livesey et al., 1998; Wells et al., 1999; Whitaker et al., 2000; Webster, 2002; Somers et al., 2003; Haskell et al., 2006; Espejo and Endres, 2007) indicated that lameness and hoof problems are most prevalent in free-stall housing but a wide range in prevalence was found within this system. The high prevalence of lameness in the yard system (loose housing) may be related to long periods of standing on wet floor resulting from accumulation of dung and urine on the earthy floor leading to a muddy surface as there is no bedding materials used in these farms. Continuous exposure to moisture softens the hoof leaving it more prone to excessive wear, dermatitis, heel horn erosion, sole ulcer, white line disease or other damage (Hultgren and Bergsten, 2001and Borderas et al., 2004).

In this study most reported cases of lameness are mainly due to hoof lesions and laminitis resulting from acidosis due to high concentrate feeding to meet the requirements for high milk yield.The high prevalence of lameness in farm I (Tie stall) is of mild type and is mainly due to leg lesions. The relationship between lameness, lying times, hygiene and the type of surface that the cow's foot is exposed is a complex one. Hoof related diseases are mostly associated with flooring surfaces. Concrete flooring can increase the incidence of lameness by causing excessive and uneven wear of the hoof, by direct damage as a result of uneven surfaces or protrusions (Fayed, 1997), by causing skin breaks that increase the risk of infectious 
diseases, and by increased impact forces that can increase the risk of damage to the corium.

In general, management that results in the cows standing longer on concrete surfaces increases the risk of sole lesions (Colam-Ainsworth $\boldsymbol{e t}$ al., 1989). Prior epidemiological surveys have shown convincingly that lameness is more prevalent where the cows walk mainly on concrete (Wells et al., 1995; Faull et al., 1996; Somers et al., 2003). There is a growing body of evidence that increased lying times have a beneficial effect on lameness prevalence and claw health. Increased time spent lying down in a clean dry comfortable stall will mean less time walking up and down alleyways and lead to cleaner drier feet (Cook, 2002).

Another study showed that cows low in the hierarchy spent more than $45 \%$ of the time standing in alleys and suffered significantly more sole, interdigital and heel lesions (Galindo and Broom, 2000). In the current study, the concrete floor in both tie and free stall house was to a great extent even and smooth but not slippery which provide good walking and standing conditions thus the hoof will not severely be damaged and lameness could be reduced. Moreover, cows are turned out of the house every day for about 8 hours in tie stall and 10 hours in free stall barn into outside area on earthy floor which greatly reduce the period of standing or walking on concrete thus lameness cases will be diminished.

Philipot et al., (1994) assessed risk factors for chronic and subacute laminitis as well as heel horn erosion and found that high steps (leading into the stall or into the milking parlour) and slopes were risk factors for sole lesions. Bell (2004) also found that steps and imperfections on the concrete flooring (such as cracks and holes) increased the risk of sole lesions. These housing defects are not recorded in this study. Furthermore, good drainage system in the tie and free stall house and daily cleaning will keep the floor clean and dry which could explain the low prevalence of severe lameness in these systems as wet standing surfaces can increase lameness. Similar results are obtained by Hultgren and Bergsten, 2001 and Borderas et al., 2004.

\section{Prevalence of mastitis}

Mastitis is an infection of the mammary gland caused mainly by Escherichia coli and Staphylococcus aureus, while a smaller incidence may be caused by Streptococcus and Klebsiella (Barkema et al., 1999a, b). Mastitis is one of the most common diseases affecting lactating dairy cows, with measures of incidence typically ranging from 25 to 40 cases per 100 cows per year in most western countries (Frei et al., 1997; Rajala and Gröhn,
1998; Barkema et al., 1999a, b; Whitaker et al., 2000; Fourichon et al., 2001). Mastitis is also an important cause of culling (Whitaker et al., 2000). Furthermore, the incidence of mastitis has been used in on-farm welfare assessment schemes for dairy cattle (Whay et al., 2003a, b).

The results in Table (4) showed that there was a significant $(\mathrm{p}<0.01)$ high prevalence of clinical mastitis in farms I (9.52\%), III (13.04\%) and IV (20.83\%) as compared to other examined farms. The results concerning the prevalence of clinical mastitis agree with prior researches (Valde $\boldsymbol{e t}$ al., 1997 and Hultgren, 2002) reporting a high prevalence of mastitis in tie stalls as compared to free stalls. Cows housed in tie stalls have higher rates of mastitis than cows housed in free stalls and that cows in confinement housing showed the highest incidence of environmental mastitis in the warm and humid months of the year, since moisture and elevated temperatures support microbial growth. From earlier epidemiological studies it have been shown that the incidence of clinical mastitis is strongly related to housing and management factors (Waage et al.,1998 and Barkema et al., 1999a, b). The high prevalence of mastitis in farm I may be attributed to unhygienic practices adopted during hand milking. In farms III and IV where the highest prevalence of mastitis was reported, the lack of house and udder cleaning procedures appears to be the most common causes for this major welfare problem.

The application of good hygienic practices in the house and during milking process may have the direct effect on the lowest prevalence of mastitis in farms V and VI. The importance of management and housing varies according to the type of bacteria responsible for the infections. For example, cases due to $E$. coli are likely related to housing conditions, but those due to $\mathrm{S}$. dysgalactiae are more likely related to milking procedures and equipment (Barkema et al., 1999a, b). As mastitis has immediate effects on milk revenue, cows with mastitis are more likely to be treated than cows suffering from lameness. Thus measures of treatment likely underestimate the incidence of some diseases and likely reflect the perceived economic return on the cost of treatment. The results of the current study may be underestimated because cases of subclinical mastitis are not included in the survey. Concerning diseases priorities in dairy cattle, Wells et al., (1998) did not consider mastitis to have important consequences for animal welfare. However, the effect of mastitis on the animal depends on the form of the disease. For instance, systemic mastitis has a longer duration of effect than localized mastitis and may have greater welfare consequences (Bareille $\boldsymbol{e t}$ al., 2003). 


\section{Prevalence of skin alterations}

Due to the pain that results from most physical injuries, occurrence of injury would seem to provide a relatively clear indication about the existence of a welfare problem. Table (5) illustrates the prevalence of skin injuries around hock joint, knee joint and at the rest of the body in cows under different housing and management systems. Regarding skin injuries around hock joint, there was a significant $(p<0.01)$ high prevalence of injuries of score 1 (hairless patch, but skin unaltered) and score 2 (reddening and/or swelling of skin) in farm I (11.9 and $11.9 \%$ respectively) as compared to other examined farms. Furthermore, there were no recorded cases for open wounds in all examined farms. Referring to injuries around knee joint, it was evident that a significant high prevalence of injuries was recorded in farms I (4.7\%) and VI (7.5\%) in comparison to other farms.

Additionally, there were no recorded injuries at the rest of the body in all investigated farms. The obtained results about prevalence of skin alterations differed from other earlier studies because difficulties in defining an injury can lead to marked differences between studies. For example, in a survey of UK dairy herds, Whitaker et al. (2000) reported that only less than $2 \%$ of cows suffered from injuries and that on most farms no injuries were seen. Enevoldsen $\boldsymbol{e t}$ al., (1994) similarly reported that between $1 \%$ and $5 \%$ of dairy cows have injuries. However, other studies reported a much higher incidence, suggesting that there were marked differences in how serious an injury had to be before it was counted. Detailed observation of injuries by Whay et al., (2003b) found that on average well over half the cows on dairy farms had some form of injury. Weary and Taszkun (2000) found that over $75 \%$ of dairy cows had some form of hock lesion. Injuries to the leg are most common in dairy cattle.

The presence of injuries, particularly swollen or ulcerated hocks, is one of the most serious threats to the welfare of dairy cattle (Whay et al., 2003a), with the majority of experts recommending some corrective action when the incidence of swollen hocks was less than $10 \%$. Hock injuries may be severe enough to result in lameness and reduce milk production and feed intake (Bareille et al., 2003). Less severe hock injuries are common in dairy cattle (Weary and Taszkun, 2000) and, along with swollen knees, are an indicator of problems in the design of housing system.

The high prevalence of skin alterations around hock and knee joints in both farms I and VI may be due to the rough and hard surface of concrete floor in these housing systems which comes in contact with the animal body during lying and standing associated with lack of bedding materials when compared to the earthy floor in other farms. Furthermore, the obtained results in farm I may be overestimated due to the small herd size. Poorly designed stalls are likely to increase the risks of other injuries to cows. Inadequate flooring can increase injuries to the knee and hocks. Too small stalls can increase the chance that cows will hit the bars of the stalls when rising or lying down. These types of injuries are more closely related to stall design than to other aspects of the housing. We need to be aware of potential shortcomings with both how injuries are assessed and the interpretation of these data, for making a good use of injuries as a measure of cow comfort. The fact that during both getting up and lying down, the front knees bear a considerable portion of the cows, weight means that hard stall flooring is likely to increase the risk of their injury. In summary, physical injury is an obvious concern for animal welfare, but difficulties in measuring the occurrence and severity of some common injuries has limited their use in assessing animal welfare.

\section{Prevalence of teat injuries}

There was a significant $(\mathrm{p}<0.01)$ greater prevalence of teat injuries in cows in farm I (14.3\%) than in other farms (Table 6) followed by farm VI (5.4\%). The severity of injuries was low in all farms and was restricted to include one teat only except farm VI in which the severity of injuries were extended to include two teats. The obtained results disagree with prior researches reported an incidence of $3.4 \%$ of teat injuries on Finnish dairy cows. Rajala and Grohn, 1998 found that teat injuries were responsible for $1.2 \%$ of the cullings on French dairy farms. Damage to teats may result from equipment, buildings and obtruding objects (Whitaker et al., 2000). In the current study, high prevalence of teat injuries in farm I and VI may be related to the rough surface of concrete floor and bad management practices during hand milking. Teat injuries are as important as skin injuries due to their marked economic effect on milk production.

\section{Cleanliness of hind legs and udder}

The results in Table (7) declared that cows in farms II, III and IV had very dirty hind legs than cows in other examined farms (90.5, 89 and $99.2 \%$ respectively). It was observed that the cleanest hind legs were found in cows in farms V and VI.With regard to the degree of cleanliness of cows' udders, it was clear that the prevalence of cows having very dirty udders was higher in farms II, III, IV and V (91.64, 91.6, 100 and $88.7 \%$ respectively) than cows in other farms Table (8). Moreover, the cleanest udder was observed in cows in farm I. These results are similar to a great extent with that obtained by (Cook 2002) who declared that tie stall cows usually 
have relatively clean lower legs, as they have less exposure to deep manure in alleys, but they tend to have higher flank and upper leg scores from lying in manure deposited on the rear of the stall. In contrast, free stall cows will have high lower leg scores due to poor alleyway hygiene. A few individual cows may have high flank and udder scores if they are lying in alleyways, but this does not usually present as a group problem.

Moreover, cows confined to a wet muddy dirt lot will have the worst hygiene picture of all, their lower legs will be filthy from walking through deep mud and their upper legs and flanks will be covered from having to lie down in the dirt. Cows housed in straw yards were less likely to be in a cleaner score category compared to cows in cubicles (Ellis et al., 2006). Proper management of housing systems including cleanliness and adequate ventilation are likely more important than housing system itself for disease prevalence. Cleanliness of hind legs and udder may be variable between different housing designs and management systems (Skoda $\boldsymbol{e t}$ al., 1991and Bowell et al., 2003).

Dirty udders and teats result in a higher workload in terms of cleaning before milking and may constitute a risk for udder health. Less soiled teats were found in farms that conducted teat dipping after milking and had increased daily cubicle maintenance time. At the same time, measures relating to good management may positively affect teat and teat tip cleanliness. Poor dairy cow hygiene score has been associated with an increase in subclinical mastitis (Schreiner \& Ruegg, 2003) and bacterial contamination of milk (Sanaa et al., 1993). Dairy cow cleanliness and hygiene are affected by the cleaning system adopted for the house and animals which may explain the variation in cow cleanliness in the current study. Cleaning of loose housing is usually difficult and the animal risk being dirty. Providing individual stalls in a free stall system makes cleaning easier and the animals are generally cleaner.

\section{Body condition score}

The majority of investigated cows in different farms had a normal or ideal body condition score (Table 9). Nevertheless, there was a higher prevalence of underconditioned (21.4\%) and over-conditioned cows $(19.1 \%)$ in farm I than in other farms which may be overestimated due to small herd size. The obtained results agree with previous study reporting no effect for housing on BCS (Fregonesi and Leaver, 2001). In contrast, (Phillips and Schofield 1994) found that cows in straw yards lost more weight and condition score than cows in cubicles. Body condition score reflects the level of nutrition and that the appetite of cow is being satisfied. It may be a useful indication of welfare when satisfaction of appetite can't be maintained, or where there are implications for disease and survival (Bienfait $\boldsymbol{e t}$ al., 1983). As it is easily measured under farm conditions, BCS may be the more useful indicator of animal welfare. In the current study, nearly all cows have an ideal BCS due to sufficient nutrition given to them according to their production in the different examined farms and to the preventive health programs adopted to minimize disease occurrence.

However, cows may physiologically have a low BCS during early lactation or due to high milk yield or pathologically due to diseases especially internal parasites. High stocking density in loose or free stall house may increase competition at the feed bunk and low ranking cows may be deprived from sufficient feeding so adequate feeding spaces must be provided (Fregonesi and Leaver, 2002). It is not feasible to assess the overall dairy cow welfare for each housing and management systems by determining a composite score from behaviour and health indicators, as this requires value judgments to be made on the weighting of individual indicators (Fraser, 1995). Nevertheless, the behaviour and health indicators can be used to identify welfare problems associated with different housing and management systems.

\section{CONCLUSION}

The welfare of dairy cows in the current study is good to a great extent in terms of cow comfort indicated by behavioural measures and skin alterations and injuries. Lameness and mastitis are still the two most important health problems affecting the welfare of dairy cows. Cows are very dirty in poorly managed yard system associated with poor stockmanship. Stockmanship and rough handling constitute the major problems in most Egyptian dairy farms. Body condition score may be a useful indicator of welfare when satisfaction of appetite can't be maintained or where there are implications for disease. The use of behaviour and health indicators to assess the welfare of dairy cows was successful for detecting responses to different housing and management systems. Further researches are needed to assign the most beneficial indicators of cow welfare.

\section{REFERENCES}

BAREILLE, N., BEAUDEAU, F., BILLON, S., ROBERT, A., AND FAVERDIN, P. 2003. Effects of health disorders on feed intake and milk production in dairy cows. Livestock Production Science, 83, 53-62.

BARKEMA, H. W., SCHUKKEN, Y. H., LAM, T. J., BEIBOER, M. L., BENEDICTUS, G., AND 
BRAND A. 1999A. Management practices associated with the incidence rate of clinical mastitis. Journal of Dairy Science, 82, 1643-1654.

BARKEMA, H. W., VAN DER PLOEG, J. D., SCHUKKEN, Y. H., LAM, T. J. G. M., BENEDICTUS, G., AND BRANDS, A. 1999B. Management style and its association with bulk milk somatic cell count and incidence rate of clinical mastitis. Journal of Dairy Science, 82, 1655-1663.

BELL, E. 2004. Description of claw horn lesions and associated risk factors in dairy cattle in the lower Fraser Valley, British Columbia. M.Sc. thesis, University of British Columbia.

BERGSTEN, C. AND HERLIN, A. H. 1996. Sole haemorrhages and heel horn erosion in dairy cows: The influence of housing system on their prevalence and severity. Acta Veterinaria Scandanavia, 37, 395-405.

BICKERT, W. G., AND CERMAK, J.. 1997. PP. 300307 in Lameness of Cattle. 3rd ed. W. B. Saunders Co., Philadelphia.

BIENFAIT, J.M., NICKS, B. AND EENAEMIE, V.C. 1983. Significance of production performance traits as indicators of animal welfare. In: Smidt, D. (Ed.), Indicators Relevant to Animal Welfare. Martinus Nijhoff, The Hague, The Netherlands, PP. 167-182.

BORDERAS, T. F., PAWLUCZUK, B., DE PASSILLÉ, A. M., AND RUSHEN, J. 2004. Claw hardness of dairy cows: Relationship to water content and claw lesions. Journal of Dairy Science, 87, 2085-2093.

BOWELL, V. A., RENNIE, L.J., TIERNEY, G., LAWRENCE, A. B. AND HASKELL, M. J. 2003. Relationships between building design, management system and dairy cow welfare. Animal Welfare, 12, 547-552.

COLAM-AINSWORTH, P., LUNN, G. A., THOMAS, R. C., AND EDDY, R. G. 1989. Behaviour of cows in cubicles and its possible relationship with laminitis in replacement dairy heifers. Veterinary Record, 125, 573-575

COOK, N.B. 2002. The influence of barn design on dairy cow hygiene, lameness and udder health. Proc. of the $35^{\text {th }}$ Ann. Conv. Amer. Assoc. Bov. Pract. vetmed.wisc.edu

EDMONSON, J., LEAN, I.L., WEAVER, L.D., FARVER, T. AND WEBSTER, G. 1989. A body condition scoring chart for Holstein dairy cows. J. Dairy Sci. 72, 68-72.

ELLIS, K.A., MIHM, M., INNOCENT, G., CRIPPS, P., MCLEAN, W.G., HOWARD, C.V. AND GROVE-WHITE, D. 2006. The effect of farming on dairy cow cleanliness in the UK and the Implications to udder health. Aspects of Applied Biology, 79, 243-245.

ENEVOLDSEN, C., GROHN, Y. T., AND THYSEN, I. 1994. Skin injuries on the body and thigh of dairycows - associations with season, claw health, disease treatement, and other cow characteristics. Acta Veterinaria Scandinavica, 35, 337-347.

ESPEJO, L. A. AND ENDRES, M. I. 2007. Herd-level risk factors for lameness in high-producing Holstein cows housed in freestall barns. Journal of Dairy Science, 90, 306-314.
ESPEJO, L.A., ENDRES, M.I. AND SALFER, J.A. 2006. Prevalence of Lameness in High-Producing Holstein Cows Housed in Freestall Barns in Minnesota. Journal of Dairy Science, 89 (8), 3052.

FAULL, W.B., HUGHES, J.W., CLARKSON, M.J., DOWNHAM, D.Y., MANSON, F.J., MERRITT, J.B., MURRAY, R.D., RUSSEL,W.B., SUTHERST, J.E. AND WARD, W.R. 1996. Epidemiology of lameness in dairy cattle: the influence of cubicles and indoor and outdoor walking surfaces. Vet. Rec. 139, 130-136.

FAYE, B., AND BARNOUIN, J. 1985. Objectivation de la proprete' des vaches laitie'res et des stabulations-L'indice de proprete'. Bull. Tech. C. R. Z. V. 59, 61-67.

FAYED, R.H. (1997): Effect of housing systems on behavior and lameness in dairy cows.Vet. Med. J., Giza, Vol.45(1); 101-110.

FOURICHON, C., BEAUDEAU, F., BAREILLE, N., AND SEEGERS, H. 2001. Incidence of health disorders in dairy farming systems in western France. Livestock Production Science, 68, 157-170.

FISHER, A.D., VERKERK, G.A., MORROW, C.J., AND MATTHEWS, L.R. 2002. The effects of feed restriction and lying deprivation on pituitary-adrenal axis regulation in lactating cows. Livestock Production Science, 73,255-63.

FRASER, A.F. 1995. Science, values and animal welfare. Exploring the 'inextricable connection'. Anim. Welfare, 4, 103-117.

FRASER, A.F. AND BROOM, D.M. 1990. Farm Animal Behaviour and Welfare. Published by Baillie`re Tindall, London, UK.

FREGONESI, J.A. AND LEAVER, J.D. 2001. Behaviour, performance and health indicators of welfare for dairy cows housed in strawyard or cubicle systems. Livestock Production Science, 68, 205-216.

FREGONESI, J. A. AND LEAVER, J. D. 2002. Influence or space allowance and milk yield level on behaviour, performance and health of dairy cows housed in strawyard and cubicle systems. Livestock Production Science, 78, 245-257.

FREI, C., FREI, P. P., STARK, D. C., PFEIFFER, D. U., AND KIHM, U. 1997. The production system and disease incidence in a national random longitudinal study of swiss dairy herds. Preventive Veterinary Medicine, 32, 1-21.

GALINDO, F. AND BROOM, D.M. 2000. The relationships between social behaviour of dairy cows and the occurrence of lameness in three herds. Research in Veterinary Science, 69, 75-79.

GOMEZ A., AND COOK, N. B. 2010. Time budgets of lactating dairy cattle in commercial free stall herds. Journal of Dairy Science, 93,5772-5781.

GREENOUGH, P.R. AND VERMUNT, J.J. 1991. Evaluation of subclinical laminitis in a dairy herd and observations on associated nutritional and management factors. Veterinary Record,128,11-17. HASKELL, M. J., RENNIE, L. J., BOWELL, V. A., BELL, M. J., AND LAWRENCE, A. B. 2006. Housing system, milk production, and zero-grazing 
effects on lameness and leg injury in dairy cows. Journal of Dairy Science, 89, 4259-4266.

HALEY, D.B., RUSHEN, J., AND DE PASSILLE, A.M. 2000. Behavioural indicators of cow comfort: activity and resting behaviour of dairy cows in two types of housing. Canadian Journal of Animal Science, 80,257-263.

HULTGREN, J. AND BERGSTEN, C. 2001. Effects of a rubber-slatted flooring system on cleanliness and foot health in tied dairy cows. Preventive Veterinary Medicine, 52, 75-89.

HULTGREN, J. 2002 . Foot/leg and udder health in relation to housing changes in Swedish dairy herds. Preventive Veterinary Medicine, 53, 167-189.

KETELAAR-DE LAUWERE, C.C., DEVIR, S., AND METZ, J.H.M. 1996. The influence of social hierarchy on the time budget of cows and their visits to an automatic milking system. Applied Animal Behavioural Science, 49, 199-211.

KREBS, S., DANUSER, J. AND REGULA, G., 2001. Using a herd health monitoring system in the assessment of welfare. Acta Agric. Scand. Sect. A, Anim. Sci. Suppl. 30, 78-81.

KROHN, C.C. AND MUNKSGAARD, L. 1993. Behaviour of dairy cows kept in extensive or intensive environments II: Lying and lying down behaviour. Applied Animal Behavioural Science, 37, 1-16.

LIVESEY, C. T., HARRINGTON, T., JOHNSTON, A. M., MAY, S. A., AND METCALF, J. A. 1998. The effect of diet and housing on the development of sole haemorrhages, white line haemorrhages and heel erosions in Holstein hiefers. Animal Science, 67, 9-16.

MANSON, F.J. AND LEAVER, J.D. 1988. The influence of concentrate amount and clinical lameness in dairy cattle. Animal Production, 47, 185-190.

MILLER, K. AND WOOD-GUSH, D. G. M. 1991. Some effects of housing on the social behavior of dairy cows. Animal Production, 53, 271-278.

MUNKSGAARD, L. AND SIMONSEN, H.B. 1996. Behavioral and pituitary adrenal-axis responses of dairy cows to social isolation and deprivation of lying down. Journal of Animal Science, 74(4),769.

NIGEL, B., AND KENNETH, V. 2009. The influence of the environment on dairy cow behavior, claw health and herd lameness dynamics. Veterinary Journal, 179(3):360-369.

PHILIPOT, J. M., PLUVINAGE, P., CIMAROSTI, I., SULPICE, P., AND BUGNARD, F. 1994. Risk factors of dairy cow lameness associated with housing conditions. Veterinary Research, 25, 244.

PHILLIPS, C.J.C. AND SCHOFIELD, S.A. 1994. The effect of cubicle and strawyard housing on behaviour, production and hoof health of dairy cows. Anim. Welfare, 3, 37-44.

RAJALA, P. J. AND GRÖHN, Y. T. 1998. Disease occurrence and risk factor analysis in Finnish Ayrshire cows. Acta Veterinaria Scandinavica, 39, 1.

REGULA G., DANUSER, J., SPYCHER, B., AND WECHSLER, B. 2004. Health and welfare of dairy cows in different husbandry systems in Switzerland. Preventive Veterinary Medicine, 66 247-264

SANAA M., POUTREL, B., MENARD, J. L. AND SERIEYS F. 1993. Risk Factors Associated with Contamination of Raw Milk by Listeria monocytogenes in dairy farms. Journal of Dairy Science, 76,2891-2898.

SCHREINER, D. A. AND RUEGG, P. L. 2003. Relationship between Udder and Leg Hygiene Scores and Subclinical mastitis. Journal of Dairy Science, 86,3460-3465.

SCOTT, E.M., NOLAN, A.M. AND FITZPATRICK, J.L., 2001. Conceptual and methodological issues related to welfare assessment: a framework for measurement. Acta Agric. Scand. Sect. A, Anim. Sci. Suppl., 30,5-10.

SINGH, S.S., WARD, W.R., LAUTENBACH, K., HUGHES, J.W., AND MURRAY, R.D. 1993 Behavior of first lactation and adult dairy cows while housed and at pasture and its relationship with sole lesions. Veterinary Record, 133, 469-474.

SKODA, S. R., THOMAS, G. D., AND CAMPBELL, J. B. 1991. Development sites and relative abundance of immature stages of stable fly (diptera: Muscidae) in beef cattle feedlot pens in eastern Nebraska. Journal of Economical Entomology, 84, 191-197.

SOMERS, J. G. C. J., FRANKENA, K., NOORDHUIZEN-STASSEN, E. N., AND METZ, J. H. M. 2003. Prevalence of claw disorders in Dutch dairy cows exposed to several floor systems.Journal of Dairy Science, 86, 2082-2093.

VALDE, J. P., HIRD, D. W., THURMOND, M. C., AND OSTERAS, O. 1997. Comparison of ketosis, clinical mastitis, somatic cell count, and reproductive performance between free stall and tie stall barns in Norwegian dairy herds with automatic feeding. Acta Veterinary Scandinavia, 38, 181-192.

WAAGE, S., SVILAND, S., AND ØDEGARD, S. A. 1998. Identification of risk factors for clinical mastitis in dairy heifers. Journal of Dairy Science, 81, 1275-1284.

WEBSTER, A. J. F. 2002. Effects of housing practices on the development of foot lesions in dairy heifers in early lactation. The Veterinary Record, 151, 9-12.

WEARY, D. M. AND TASZKUN, I. 2000. Hock lesions and free-stall design. Journal of Dairy Science, 83, 697-702.

WELLS, S. J., GARBER, L. P., AND WAGNER, B. A. 1999. Papillomatous digital dermatitis and associated risk factors in US dairy herds. Preventive Veterinary Medicine, 38, 11-24.

WELLS, S. J., OTT, S. L., AND HILLBERG SEITZINGER, A. 1998. Key health issued for dairy cattle - new and old. Journal of Dairy Science, 81, 3029-3035

WELLS, S. J., TRENT, A. M., MARSH, W. E. WILLIAMSON, N. B., AND ROBINSON, R. A. 1995. Some risk factors associated with clinical lameness in dairy herds in Minnesota and Wisconsin. Veterinary Record, 136, 537-540.

WHAY, H. R., MAIN, D. C. J., GREEN, L. E., AND WEBSTER, A. J. F. 2003a. Animal-based measures for the assessment of welfare state of dairy 
cattle, pigs and laying hens: Consensus of expert opinion. Animal Welfare, 12, 205-217.

WHAY, H. R., MAIN, D. C. J., GREEN, L. E., AND WEBSTER, A. J. F. 2003b. Assessment of the welfare of dairy cattle using animal-based measurements: Direct observations and investigation of farm records. The Veterinary Record, 153, 197-202.

WHITAKER, D. A., KELLY, J. M., AND SMITH, S. 2000. Disposal and disease rates in 340 British dairy herds. Veterinary Record, 146, 363-367
How to cite this article:

Ahmed.S. Mostafa and Hesham. A. Mahran, 2016. Assessment of Welfare and Health of Dairy Cows Under Different Housing and Management Systems. Journal of Applied Veterinary Sciences, 1(1):56-69. DOI : https://dx.doi.org/10.21608/javs.2016.62122 